\title{
Олена СИДОРОВИЧ
}

доктор економічних наук, доцент, Західноукраїнський національний університет, Тернопіль, Україна, o.sydorovych@wunu.edu.ua

ORCID ID: 0000-0002-4605-3533

\section{Святослав ГЕРЧАКІВСЬКИЙ}

кандидат економічних наук, доцент, Західноукраїнський національний університет,

Тернопіль, Україна, s.herchakivskyi@wunu.edu.ua

ORCID ID: 0000-0003-4127-8044

\section{ІНФОРМАЦЙНЕ ЗАБЕЗПЕЧЕННЯ МИТНОї СПРАВИ УКРӒ̈НИ В КОНТЕКСТI ЦИФРОВОї СТРАТЕГIї РОЗВИТКУ СУСПІАЬСТВА}

Вступ. У сучасних умовах глобальних трансформаційних перетворень, впливу пандемічних викликів і загроз ключову роль відіграє рівень цифровізації державного управління загалом та рівень інформаційного забезпечення фріскальних органів зокрема. Використання ефективних технологій інформатизації митних органів держави створює сприятливі умови для переміщення товарів через державний кордон шляхом спрощення, пришвидшення та вдосконалення процедур митного оформлення та митного контролю. На сьогодні існує нагальна потреба в уніфрікації національної законодавчої бази у сфрері митної справи до міжнародних стандартів, вдосконаленні технологічного, інституційного та інфраструктурного напряму реформування митних органів держави та активізації процесів діджиталізації митної політики України.

Мета - дослідити специфріку діяльності й завдання рефоормування інформаційного забезпечення діяльності митних органів держави, окреслити пріоритети та перешкоди підвищення ефективності діяльності митних інституцій як України, так і країн економічного авангарду в контексті цифрової стратегії розвитку суспільства.

Методи. У дослідженні особливостей інформаційного забезпечення митної справи в Україні та рівня інформатизації митних органів держави використовували загальнонаукові і спеціальні методи дослідження, а саме: аналіз, синтез, узагальнення та статистичний.

Результати. В результаті проведеного дослідження інформаційного забезпечення митної справи України систематизовано базис ії здійснення, проаналізовано особливості трансформаційних перетворень інфрормаційного забезпечення митних органів держави. Проаналізовано досвід інформатизації митного простору економічно розвинених країн в умовах цифровізації економіки. Окреслено сучасні інформаційні системи митних

() Олена Юріївна Сидорович, Святослав Дем'янович Герчаківський, 2021 
органів України й особливості їх функціонування. Деталізовано переваги та перешкоди приєднання митних органів держави до Конвенції про процедуру спільного транзиту. Визначено проблемні аспекти, що перешкоджають підвищенню ефективності інформаційного забезпечення в ДМС України.

Перспективи. У подальших наукових дослідженнях необхідно зосередити увагу на оцінці рівня ефективності системи інформаційного забезпечення митної справи в Україні та розвинених державах світу, аналізі безпекових, фріскальних та економічних ефректів цифрових трансформацій митних процедур, напрямах імплементації передових практик інфрорматизації діяльності митних інституцій держави.

Ключові слова: цифровізація, “цифрова митниця”, електронне декларування, Конвенція про процедуру спільного транзиту.

Табл.: 4, бібл.: 18.

\section{Елена СИДОРОвИч}

доктор экономических наук, доцент, Западноукраинский национальный университет, Тернополь, Украина

\section{Святослав ГЕРЧАКИВСКИЙ}

кандидат экономических наук, доцент, Западноукраинский национальный университет, Тернополь, Украина

\section{ИНФОРМАЦИОННОЕ ОБЕСПЕЧЕНИЕ ТАМОЖЕННОГО ДЕАА УКРАННЫ В КОНТЕКСТЕ ЦИФРОВОЙ СТРАТЕГИИ РАЗВИТИЯ ОБЩЕСТВА}

Введение. В современных условиях глобальных трансформационных преобразований, влияния пандемических вызовов и угроз ключевую роль играет уровень цифровизации государственного управления в целом и уровень информационного обеспечения фрискальных органов в частности. Использование эфффективных технологий информатизации таможенных органов государства создает благоприятные условия для перемещения товаров через государственную границу путем упрощения, ускорения и совершенствования процедур таможенного оформления и таможенного контроля. На сегодня существует насущная необходимость в унификации национальной законодательной базы в сфере таможенного дела с международными стандартами, совершенствовании технологического, институционального и инфраструктурного направления рефоомирования таможенных органов государства и активизации процессов диджитализации таможенной политики Украины.

Цель - исследовать специфрику деятельности и задачи рефрормирования инфрормационного обеспечения деятельности таможенных органов государства, определить приоритеты и препятствия повышения эффрективности деятельности таможенных органов как Украины, так и стран экономического авангарда в контексте цифровой стратегии развития общества.

Методы. При исследовании особенностей информационного обеспечения таможенного дела в Украине и уровня информатизации таможенных органов государства использовалась совокупность общенаучных и специальных методов исследования, которые включают: анализ, синтез, обобщение и статистический. 
Результаты. В результате проведенного исследования информационного обеспечения таможенного дела Украины систематизирован базис его осуществления, проанализированы особенности трансформационных преобразований информационного обеспечения таможенных органов государства. Проанализирован опыт информатизации таможенного пространства экономически развитых стран в условиях цифровизации экономики. Определены современные инсрормационные системы таможенных органов Украины и особенности их функционирования. Детализировано преимущества и препятствия присоединения таможенных органов государства к Конвенции о процедуре общего транзита. Определены проблемные аспекты, препятствующие повышению эфрфективности информационного обеспечения в ГТС Украины.

Перспективы. В дальнейших научных исследованиях необходимо сосредоточить внимание на оценке уровня эфорективности системы информационного обеспечения таможенного дела в Украине и развитых странах мира, анализе фискальных и экономических эфрфектов цифровых трансформаций таможенных процедур, направлениях имплементации передовых практик информатизации деятельности таможенных учреждений государства.

Ключевые слова: цифровизация, “цифровая таможня”, электронное декларирование, Конвенция о процедуре общего транзита.

\section{Olena SYDOROVYCH}

Dr. Sc. (Economics), Assoc. Prof., West Ukrainian National University, Ternopil, Ukraine,

o.sydorovych@tneu.edu.ua

ORCID ID: 0000-0002-4605-3533

\section{Sviatoslav HERCHAKIVSKY}

Ph. D. (Economics), Assoc. Prof., West Ukrainian National University, Ternopil, Ukraine,

s.herchakivskyi@wunu.edu.ua

ORCID ID: 0000-0003-4127-8044

\section{INFORMATION SUPPORT OF UKRAINIAN CUSTOMS AFFAIRS IN THE CONTEXT OF DIGITAL SOCIETY DEVELOPMENT STRATEGY}

Introduction. In the current conditions of global transformations, the impact of pandemic challenges and threats, the level of digitalization of public administration in general and the level of information support of fiscal authorities in particular play a key role. The use of effective technologies of informatization of the customs authorities of the state creates favorable conditions for the movement of goods across the state border by simplifying, accelerating and improving the procedures of customs clearance and customs control. Today there is an urgent need to unify the national legal framework in the field of customs to international standards, improve the technological, institutional and infrastructural direction of reforming the customs authorities of the state and to intensifyty the processes of digitalization in Ukrainian customs policy .

The purpose of the article is to study the specifics of the activities and tasks of reforming the information support in the state customs authorities, to outline priorities and obstacles to improving the efficiency of customs institutions in Ukraine and in the economic avant-garde countries on the context of digital strategy of society. 
Methods. In studying the features of information support of customs in Ukraine and the level of informatization of customs authorities in particular, a set of general scientific and special research methods was used, covering: analysis and synthesis, generalization and statistical.

Results. As a result of the study of information support of the customs of Ukraine, the basis of its implementation is systematized, the transformational features of information support of the customs authorities of the state are analyzed. The experience of informatization of the customs space of economically developed countries in the conditions of digitalization of the economy is analyzed. Modern information systems of the customs authorities of Ukraine and the peculiarities of their functioning are outlined. The advantages and obstacles of accession of the customs authorities of the state to the Convention on the procedure of joint transit are detailed. The problematic aspects that prevent the increase of efficiency of information support in the LCA of Ukraine are determined.

Prospects. Further research is planned to focus on assessing the level of efficiency of the customs information system in Ukraine and developed countries, analysis of security, fiscal and economic effects of digital transformations of customs procedures, areas of implementation of best practices of informatization of customs institutions.

Keywords: digitalization, "digital customs", electronic declaration, Convention on the procedure of joint transit.

JEL Classification: H30.

Постановка проблеми. Впродовж останніх десятиліть в глобальному вимірі відбувається докорінний перехід від системних процесів індустріальної економічної моделі до "цифрової економіки", що розвивається на основі “цифрової" стратегії розвитку суспільства. Ключова відмінність цифрових трансформацій зводиться не лише до використання цифрових та інформаційно-комунікативних комп'ютерних технологій, які властиві також інформаційній парадигмі розвитку, а й до докорінного перетворення усіх сорер розгортання соціальних, суспільних та управлінських процесів на базі новітніх цифрових технологій; формування нових кіберфізичних систем, в яких усі елементи і учасники, безперервно взаємодіючи між собою, забезпечують постійну оптимізацію інтегрованої ІТ-системи.

Згідно з експертними оцінками, цифровізація усіх сфер життєдіяльності суспільства робить значний внесок у ВВП провідних країн G-20, наближаючись до 8\%, при цьому стимулюючи пожвавлення економічних і соціальних процесів, створюючи інтелектуальні цифрові мережі, які фундаментально змінюють традиційну торгівлю в межах країни та за ії межами, а також переводячи діяльність фіскальних органів в призму цифрової активності. Активізація процесів діджиталізації усіх галузей економіки і сорер суспільного життя - об'єктивно існуюче міжнародне економічне явище, набувши швидкого поширення, сприяла появі нової концепції реалізації митної справи на засадах цифрової стратегії розвитку суспільства.

Мета статті полягає в систематизації характеристик розвитку інформаційного забезпечення митної справи та формування електронного митного середовища в Україні, окресленні пріоритетів і перешкод підвищення ефективності діяльності як вітчизняних митних інституцій, так і країн економічного авангарду в контексті цифрової стратегії розвитку суспільства. 
Аналіз останніх досліджень і публікацій. Поява концепції "цифрового врядування” (Digital Era Governance, DEG), що визначалась як перехід від "Нового державного управління” (New Public Management) до новітнього "цифрового" управління, завдячує теоретичним підходам П. Данлеві, X. Маргетса, С. Бастоу та Дж. Тінклера. Вчені, окресливши базові напрями ери цифрового врядування, внесли до їх переліку: реінтенграцію (що передбачала залучення усіх учасників інформаційних комунікацій до взаємодії на якісно нових умовах), “клієнто-орієнтований холізм" (як передумову реорганізації управлінських підходів для забезпечення потреб всіх груп користувачів) та цифровізацію (що охоплювала використання потенціалу цифрового зберігання, обробки інформації, її аналізу для інформаційних комунікацій та трансформації управління) [1].

В українському науковому просторі питання інформатизації та цифровізації митних процедур, інформаційного забезпечення митної справи тощо висвітлені в роботах А. Войцещука [2], Р. Давидова [3], Л. Івашової та Л. Кийди [4, с. 146-152], П. Пашка [5, с. 53-59], М. Разумея [6] та інших.

Виклад основного матеріалу дослідження. Глобалізаційні перетворення економік кінця $X X$ - початку XXI ст. ознаменували пошук напрямів оптимізації та вдосконалення митної справи, спрощення та уніфікацію митних процедур, скорочення часу та обсягів здійснення митних формальностей. Ключовим підгрунтям досягнення означених напрямів $€$ підвищення ефективності протидії митним деліктам, інформатизація митної справи та оптимізація інформаційного забезпечення митного контролю і митного офрормлення.

Широке розповсюдження інформаційних та електронних технологій в митних інституціях провідних країн світу розпо- чалось в останніх десятиліттях минулого століття. Аналізуючи генезис поширення інформаційних технологій митного оформлення в світовій практиці, традиційно згадують практичний досвід таких країн, як: Німеччина, Японія, Корея, США, Китай та Франція.

Найбільш раннє розповсюдження принципу “віддаленого декларування" мало місце в Японії в 1980-х - 1990-х рр. на основі створення автоматизованої системи обробки даних про зовнішньоекономічну діяльність (NACCS), в результаті існування якої декларант міг дистанційно задекларувати товар та автоматично отримати розрахунок необхідної суми митних платежів при експорті чи імпорті товарів. При цьому система, охоплюючи інформацію від суб'єктів ЗЕД та контролюючих органів, на основі встановлених критеріїв ризиків визначала процедури митного оформлення, для здійснення яких необхідне було проведення додаткового митного контролю.

Система автоматизації процесів митного оформлення та контролю ACS (Автоматизована комерційна система) й електронного декларування була створена в США ще у 1984 р., ресрормована у Митне автоматизоване комерційне середовище (ACE) у 1990-х рр., та видозмінена внаслідок подій 11.09.2001 р. в єдину службу митного, прикордонного контролю та міжнародної торгівлі. На сьогодні усі вантажі, які імпортують в країну, мають бути задекларовані відповідною транспортною компанією загального призначення (VOCC) або компанією (NVOCC), що має відповідну ліцензію на здійснення міжнародних перевезень за добу до відправлення судна з пункту навантаження через автоматизовану систему декларування (AMS) [7].

Вперше автоматизовану електронну систему UNI-PASS, яка б повною мірою забезпечувала процедури митного оформ- 
лення й адміністрування в світовому митному просторі було створено в Кореї у 2001 р. Постійно вдосконалюючись та доповнюючись від моменту створення, на сьогодні це - інтегрована інформаційна система, що охоплює велику кількість суб'єктів зовнішньоекономічної діяльності, державних інституцій та відомств, фрінансових посередників, митно-брокерські фірми, судові компанії, авіакомпанії тощо. Система, працюючи за принципом “єдиного вікна", вміщує нормативно-правову базу, первинні документи, інформацію про банківське обслуговування, розрахунок сум податкових та митних платежів, систему управління ризиками й індикатори аналізу для проведення митного аудиту. При поданні декларації суб'єктом ЗЕД, вона в режимі реального часу потрапляє у відповідні державні структури, де здійснюють аналіз ризиків та визначають доцільність селективного відбору товарів для огляду чи здійснення більш детального митного контролю.

Автоматизована система обробки відомостей NACCS (Nippon Automated Cargo and Port Consolidated System), яка $є$ взірцем успішної узгодженої взаємодії кількох IT-систем суб'єктів ЗЕД та митних інституцій держави, поділяючись на повітряну (airNACCS) і морську (sea-NACCS), використовується в Японії.

Доволі успішним є досвід Пакистану, де із запровадженням програмного продукту WeBOC ("Web based one custom", доступ до якого може забезпечуватись навіть з мобільних телефонів), рівень податкових та митних надходжень зріс на $47 \%$.

Активізація процесів "глобалізації й лібералізації торгівлі, значне зростання її обсягів та приріст електронної торгівлі, широке використання інформаційних технологій, забезпечення більш ефективних електронних послуг" сприяли запуску у 2003 р. на теренах Європейського Союзу програми
“Електронна митниця”. 12 з 25 країн-учасниць в складі Бельгії, Німеччини, Італії, Іспанії, Швеції, Великобританії, Чеської Республіки, Данії, Португалії, Нідерландів, Австрії та Польщі стали учасницями пілотного проекту Системи експортного контролю (ECS) [5, с. 53-59].

У 2008 р. на основі рішення Європарламенту № 70/2008/EC було здійснено перелік заходів, що сприяли переходу на електронне управління митними процедурами, забезпечення безперебійної інформаційної взаємодії між митними інституціями країн-членів ЄС та створення безпаперового митного середовища. При цьому термін "paperless environment" (безпаперове ceредовище) як характеристику функціонування "безпаперової митниці" фахівці Всесвітньої митної організації визначили не лише як передумову звільнення від використання паперових документів, а, здебільшого, як необхідний етап переходу до принципу “єдиного вікна”.

Зазначимо, що формування механізму “електронна митниця" було започатковано в ЄС ще у 1997 р. із запровадженням системи електронного обміну митними деклараціями “Нова комп'ютеризована транзитна система" [8]. Разом з тим, для прискорення переведення митних операцій і процедур між митними органами країн-учасниць і суб'єктами ЗЕД та активізації використання IT-технологій у ВМО було сформовано “Методичні рекомендації щодо розширення використання інформаційних технологій”.

Відповідно до означених документів та здійснюваних заходів, поняття "електронна митниця" втілює комплекс комп'ютерних інформаційних технологій реалізації митних формальностей, що охоплюють: електронну обробку, подання документів для митного оформлення, митного декларування; автоматизацію взаємодії митних інституцій з суб'єктами ЗЕД за принципом "24/7"; 
електронний калькулятор митних платежів та можливість їх сплати в онлайн форматі; мобільні послуги учасникам ЗЕД; електронне оформлення повернення товарів і сплачених за них митних платежів; можливість подання попередньої додаткової інформації до навантаження товару тощо.

На основі змін, внесених до Митного кодексу ЄС у 2016 р., митні декларації необхідно подавати в електронному форматі через систему EDI, використання якої дало змогу окреслити низку переваг, а саме: зменшення фрізичного контакту між представниками бізнесу та контролюючими інституціями; мінімізація корупційних ризиків; автоматизація процесу митного декларування для суб'єктів ЗЕД; оптимізація рівня митного контролю через ефективну систему селекції ризиків на етапі подання електронних декларацій. Тому, якщо у 2016-2017 рр., за даними офріційних звітів ВМО, загальний відсоток подання електронних митних декларацій у Європейському регіоні перевищував $90 \%$ (див. таб. 1), то на сьогодні він становить майже 99\%.

Аналіз динаміки кількості оформлених декларацій впродовж означеного періоду в
Україні демонструє зростання кількості подання декларацій переміщення товарів за електронною формою (табл. 2). При цьому, якщо відсоток подання електронних декларацій у 2014 р. становив $86,1 \%$, то в подальшому спостерігалося його підвищення до $90,6 \%$ у 2015 р., $92,3 \%$ у 2016 р., $93,8 \%$ у 2017 р. та $94,78 \%$ у 2018 р.

Хронологічно запровадження митних інформаційних технологій в Україні розпочалося в 1992 р., а імплементація системи “Електронна митниця" була запроваджена, починаючи з 2005 року. У 1992 р., у вітчизняному митному середовищі мало місце формування бази даних електронних копій вантажних митних декларацій з паперових носіїв, їх аналіз, обробка та систематизація показників митної статистики. Впродовж 1994-2005 рр., окрім створення центральної бази електронних копій митних декларацій, було започатковано формування телекомунікаційної мережі з відомчою електронною поштою та комплексною системою захисту інформації, автоматизовано процеси митного оформлення та контролю доставки вантажів на основі новітніх для того часу автоматизованих інформаційних систем.

Аналіз подання електронних митних декларацій в територіальному вимірі

Таблиця 1 у 2016-2017 pp.*

\begin{tabular}{|c|c|c|c|c|}
\hline \multirow[t]{2}{*}{ Perion } & \multicolumn{2}{|c|}{$\begin{array}{l}\text { Кількість митних } \\
\text { декларацій, млн }\end{array}$} & \multicolumn{2}{|c|}{$\begin{array}{c}\text { Відсоток електронних } \\
\text { декларацій,\% }\end{array}$} \\
\hline & Імпорт & Експорт & Імпорт & Експорт \\
\hline $\begin{array}{l}\text { Північна Америка, Південна Америка, } \\
\text { Центральна Америка та Кариби }\end{array}$ & 68,5 & 26,3 & 85,2 & 87,3 \\
\hline Західна та Центральна Африка & 1,2 & 0,1 & 85,5 & 89,6 \\
\hline Східна та Південна Афррика & 7,4 & 7,3 & 92,7 & 95,8 \\
\hline північ Афррики, Близький та Середній Схід & 6,1 & 1,7 & 97 & 95 \\
\hline $\begin{array}{l}\text { Далекий Схід, Південна та Південно-Східна Азія, } \\
\text { острови Тихого океану }\end{array}$ & 92 & 115,7 & 91,6 & 93,6 \\
\hline Європейський регіон & 171,7 & 97,2 & 85,9 & 91,9 \\
\hline
\end{tabular}

* Складено на основі даних щорічного звіту ВМО. 
Аналіз оформлення митних декларацій в Україні впродовж 2014-2018 рр.*

\begin{tabular}{|c|c|c|c|c|c|c|}
\hline Показник & $\begin{array}{l}\text { Од. } \\
\text { виміру }\end{array}$ & 2014 p. & 2015 p. & 2016 p. & 2017 p. & 2018 p. \\
\hline $\begin{array}{l}\text { Оформлено митних декларацій форми } \\
\text { МД-2: }\end{array}$ & $\begin{array}{l}\text { muc. } \\
\text { um. }\end{array}$ & 3113,4 & 2791,2 & 3088,0 & 3569,4 & 3953,2 \\
\hline на ввезення (надходження) & тис. шт. & 1755,4 & 1510,1 & 1808,7 & 2148,5 & 2472,2 \\
\hline на вивезення (пересилання) & тис. шт. & 884,8 & 870,1 & 852,2 & 940,0 & 989,7 \\
\hline на внутрішній транзит (каботаж) & тис. шт. & 87,1 & 73,3 & 79,4 & 90,2 & 92,7 \\
\hline на прохідний транзит ${ }^{1}$ & тис. шт. & 385,9 & 337,7 & 347,6 & 390,7 & 398,6 \\
\hline $\begin{array}{l}\text { Оформлено митних декларацій форми } \\
\text { МД-2 за процедурою електронного } \\
\text { декларування: }\end{array}$ & $\begin{array}{l}\text { muc. } \\
\text { um. }\end{array}$ & 2680,8 & 2530,7 & 2851,8 & 3349,3 & 3746,9 \\
\hline на ввезення (надходження) & тис. шт. & 1611,9 & 1432,0 & 1736,4 & 2089,3 & 2417,1 \\
\hline на вивезення (пересилання) & тис. шт. & 820,9 & 830,9 & 829,1 & 929,5 & 982,1 \\
\hline на внутрішній транзит (каботаж) & тис. шт. & 80,5 & 70,4 & 77,2 & 88,0 & 91,7 \\
\hline на прохідний транзит ${ }^{1}$ & тис. шт. & 167,6 & 197,3 & 209,1 & 242,5 & 256,0 \\
\hline Оформлено інших митних документів²: & тис. шт. & - & 1361,1 & 1502,6 & 1667,5 & 1727,2 \\
\hline квитанцій МД-1 & тис. шт. & - & 1307,7 & 1428,3 & 1579,7 & 1637,1 \\
\hline оглядових розписів М 15 & тис. шт. & - & 32,4 & 47,7 & 44,8 & 41,9 \\
\hline митних декларацій М-16 & тис. шт. & - & 21,0 & 26,7 & 42,9 & 48,3 \\
\hline $\begin{array}{l}\text { Кількість осіб, які здійснюють операції } \\
\text { з товарами та перебувають на централізо- } \\
\text { ваному обліку: }\end{array}$ & тис. осіб & 64,6 & 79,2 & 93,4 & 105,0 & 115,7 \\
\hline взятих на облік з початку року & тис. осіб & 11,5 & 12,5 & 14,3 & 13,6 & 13,5 \\
\hline $\begin{array}{l}\text { здійснювали митні формальності з товара- } \\
\text { ми з початку року }\end{array}$ & тис. осіб & 35,2 & 37,4 & 40,9 & 44,3 & 46,8 \\
\hline
\end{tabular}

${ }^{1}$ включаючи електронні документи контролю доставки на основі накладних ЦІМ/YMBC [CIM/SMGS] та книжок MДП [Carnet TIR];

2 збір та узагальнення даної інформації у 2014 р. не здійснювали.

*Складено на основі [10].

У 2006 р. з прийняттям Концепції створення, упровадження і розвитку системи електронного декларування товарів було започатковано необхідні умови для використання цифрових та інформаційних технологій електронного документообігу з допомогою електронного цифрового підпису, який на основі відповідного програмного забезпечення дав змогу оптимізувати процеси електронного декларування між митними органами держави та суб'єктами ЗЕД [11].

Черговим кроком активізації електронного декларування стало затвердження в 2008 р. Концепції створення багатофункціональної комплексної системи "Електронна митниця" з окресленням трьох етапів її реалізації.

І етап. 2009 рік - формування законодавчих, нормативно-правових та інституційних основ для застосування інформаційно-телекомунікаційних технологій у електронному документообігу суб'єктів ЗЕД, митних інституцій держави та інших органів державної влади; оптимізація функціонування автоматизованих систем митної служби з метою технологічного забезпечен- 
ня безперебійності механізму електронного митного декларування, безперервності потоку, накопичення, обробки та забезпечення захисту електронної митної інформації.

II етап. 2009-2010 рр. - активне створення підсистем забезпечення комплексної системи "Електронна митниця", зокрема в частині:

а) управління та адміністрування, шляхом раціоналізації рішень органів управління митною справою щодо контролю за умовами, процедурами та витратами часу суб'єктів ЗЕД на здійснення митних формальностей та чіткого алгоритму виконання рішень працівниками функціональних підрозділів митних органів за умови необхідності посиленого митного контролю, огляду, затримання, адміністративного арешту тощо;

б) програмного забезпечення механізму електронного декларування шляхом подальшої розробки та вдосконалення програмного забезпечення на різних рівнях;

в) гармонізації системи електронної взаємодії вітчизняної системи електронного декларування з комп'ютеризованою транзитною системою ЄС та забезпечення сумісності з іншими системами контролю за переміщенням вантажів відповідно до вимог ВМО;

г) електронного цифрового підпису та захисту інформації, на основі якого було створено Акредитований центр сертифрікації ключів, який покращив електронний документообіг між суб'єктами ЗЕД та митними органами.

III етап. 2010-2013 рр. - завершення впровадження системи автоматизованого електронного документообігу, митного оформлення товарів і транспортних засобів на всіх рівнях митної системи, введення в дію механізму аналізу ризиків.

Автоматизований аналіз та управління ризиками під час митного оформлення ван- тажів митними органами держави здійснюється у вигляді спеціального модуля автоматизованої системи аналізу й управління ризиками (АСАУР), що імплементований до автоматизованої системи митного оформлення вантажів. За його допомогою на підставі усіх введених профрілів ризику здійснюється оцінка ризику декларації, поданої до митного оформлення, та фрормується перелік митних процедур з деталізацією необхідних заходів для перевірки законності здійснення зовнішньоекономічної операції (уточнення, інструкції чи пояснення, які стосуються застосування, за потреби - уточнення про товари чи інші умови, за яких застосування митних процедур є обов'язковим) [11]. На сьогодні до системи АСАУР внесено 105 алгоритмів (профрілів ризику), більш ніж 700 підалгоритмів, близько 100000 комбінацій індикаторів ризику, більш ніж 650 доповнень до профрілів ризику оперативного характеру.

Важливим кроком на третьому етапі запровадження багатофункціональної комплексної системи "Електронна митниця" стало прийняття Концепції інтегрування системоутворюючих компонентів технічних та спеціальних засобів митного контролю з автоматизованою системою митного офрормлення ДМСУ. Згідно з цим програмним документом було встановлено мету, ключові цілі та пріоритетні заходи інтегрування системоутворюючих компонентів технічних і спеціальних засобів митного контролю та автоматизованої системи митного оформлення, окреслено базові засади інформаційно-телекомунікаційного, кадрового та спеціального технічного забезпечення Єдиної автоматизованої інформаційної системи (ЄAIC) [12]. Загальном ЄAIC $€$ багатофункціональною інтегрованою автоматизованою системою, яка забезпечує інформаційну підтримку та супроводження державної митної справи в Україні і стано- 


\section{МИТНА СПРАВА}

вить сукупність кількох взаємопов'язаних інформаційних систем, зокрема автоматизованої інформаційної системи "Центр", телекомунікаційної системи "Електронна пошта" та інших систем, програмно-інформаційних комплексів (табл. 3) [13].

Функціонування ЄAІC дає змогу: контролювати доставку вантажів до митниць призначення; приймати та обробляти дані вантажних митних декларацій, здійснювати їх форматологічний контроль; формувати звіти та проводити аналітичну роботу в різних сорерах діяльності митних органів, систематизувати дані митної статистики; користуватися різними довідниками (що містять інформацію про товарну номенклатуру, митний тариф, довідники валют світу тощо); контролювати застосування спеціальних санкцій до порушників законодавства та здійснювати обмін оперативною інформацією про митні правопорушення; проводити дистанційне навчання митних

\section{Завдання, функції та структура ЄАIC Держмитслужби [15]}

\begin{tabular}{|c|c|c|}
\hline Завдання & Функції & Структура \\
\hline $\begin{array}{l}\text { - інформаційна підтримка процесів } \\
\text { функціонування та шляхів підви- } \\
\text { щення ефективності й оперативності } \\
\text { діяльності митних органів під час ви- } \\
\text { конання ними законодавчо встанов- } \\
\text { лених завдань і функцій; } \\
\text { - збір, обробка, накопичення, аналіз, } \\
\text { резервне копіювання та збереження, } \\
\text { передавання інформації у сфері мит- } \\
\text { ної справи шляхом об'єднання відпо- } \\
\text { відних інформаційних ресурсів митних } \\
\text { органів, спеціалізованих митних уста- } \\
\text { нов та організацій, інформаційних ре- } \\
\text { сурсів центральних органів виконавчої } \\
\text { влади, інформаційних ресурсів інших } \\
\text { недержавних установ (організацій, } \\
\text { підприємств) - субєктів ЗЕД, митних } \\
\text { і правоохоронних органів інших країн; } \\
\text { та забезпечення їх інформаційної } \\
\text { взаємодії; } \\
\text { контроль за переміщенням вантажів, } \\
\text { що перебувають під митним контро- } \\
\text { лем як через митний кордон України, } \\
\text { так і в іії межах; } \\
\text { - автоматизація фрормування даних } \\
\text { митної статистики та підвищення її } \\
\text { достовірності; } \\
\text { - підвищення есрективності контролю } \\
\text { своєчасності, достовірності, повно- } \\
\text { ти нарахування та сплати податків і } \\
\text { зборів, які справляються при пере- } \\
\text { міщенні товарів через митний кордон } \\
\text { України; } \\
\text { - мінімізація часу та витрат на митне } \\
\text { оформлення товарів і транспортних } \\
\text { засобів, що переміщуються через } \\
\text { митний кордон України, зменшення } \\
\text { часовихі фінансових витрат на інфор- } \\
\text { маційно-пошукову, розрахункову та } \\
\text { аналітичну роботу митних органів; }\end{array}$ & 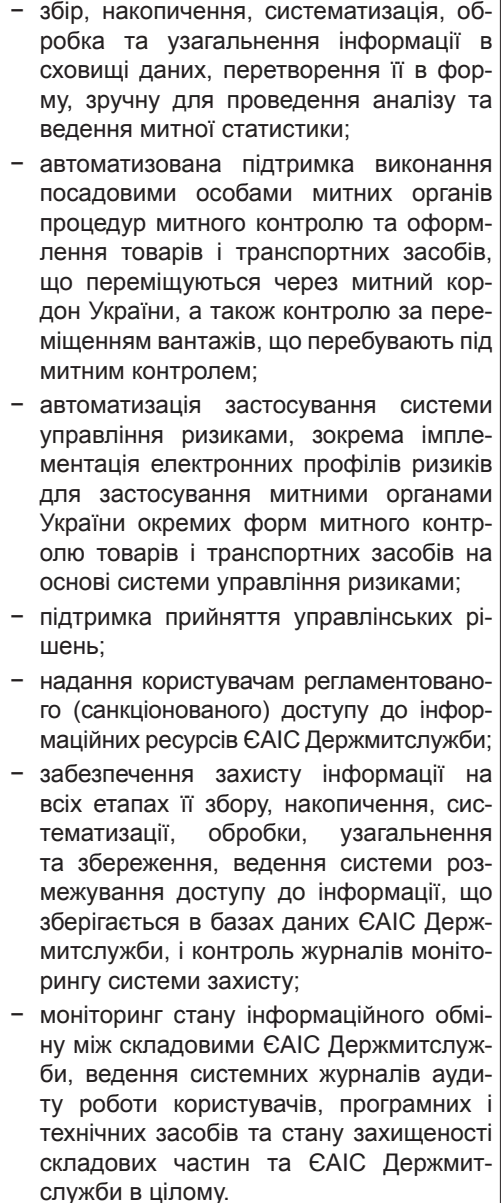 & $\begin{array}{l}\text { - автоматизована інформацій- } \\
\text { на система “Центр”; } \\
\text { - АСмО та локальні підсисте- } \\
\text { ми митних органів, спеціалі- } \\
\text { зованих митних установ та } \\
\text { організацій, що взаємодіють } \\
\text { із АІС «Центр»; } \\
\text { - відомча телекомунікаційна } \\
\text { мережа Держмитслужби; } \\
\text { - локальні обчислювальні ме- } \\
\text { режі митних органів, спеціа- } \\
\text { лізованих митних установ та } \\
\text { організацій; } \\
\text { - інформаційно-телекомуні- } \\
\text { каційний комплекс Держ- } \\
\text { митслужби «Електронна } \\
\text { пошта»; } \\
\text { - адміністративно-правова ін- } \\
\text { формаційна підсистема; } \\
\text { - підсистема інформаційного } \\
\text { забезпечення; } \\
\text { - система електронного доку- } \\
\text { ментообігу Держмитслужби; } \\
\text { - комплексна система захисту } \\
\text { інформації; } \\
\text { - підсистема криптографічно- } \\
\text { го захисту інформації; } \\
\text { - система електронного циф- } \\
\text { рового підпису Держмит- } \\
\text { служби. }\end{array}$ \\
\hline
\end{tabular}


працівників; формувати, здійснювати обмін інформацією $з$ державними органами та недержавними організаціями.

Зазначимо, що після реорганізації ДФС України та утворення двох відокремлених служб, з метою надання якісних інформаційних е-сервісів, відбувається інтеграція інфрормаційно-телекомунікаційних систем та інформаційних ресурсів Державної податкової та Державної митної служби України. Зокрема, згідно з Наказом Мінфіну від 10.06.2020 № 286 [16] має місце координація та взаємодія реєстру осіб, які здійснюють операції з товарами, що належить до Єдиної автоматизованої інформаційної системи органів Держмитслужби, а також Єдиного банку даних про платників податків - юридичних осіб і Державного реєстру фрізичних осіб - платників податків.

В разі взяття на облік особи, яка здійснює операції з товарами чи зміни у реєстраційних даних осіб (зміна керівника, бухгалтера, адреси (місця проживання) тощо), передбачена координація відомостей в програмному забезпеченні інформаційних систем ДПС та ДМС України.

3 метою активізації застосування новітніх технологій, що перетворюють митне адміністрування в швидкий і високотехнологічний процес шляхом постійного інноваційного вдосконалення процедур митного оформлення та митного контролю у рамках виконання Стратегічних ініціатив розвитку ДФС до 2020 р., впроваджується концепція “Смарт-митниці”. Відповідно до неї буде використовуватися інтелектуальна система оцінки ризиків, єдиний портал надання дозвільних документів (надаватиметься 31 дозвільний документ), електронне декларування, здійснюватиметься управління та контроль над усіма ланцюгами поставок, постмитний контроль та постаудит, застосовуватимуться високотехнологічні технічні засоби митного контролю. Очікується, що декларування товарів в рамках "Смартмитниці" здійснюватиметься за принципом "Єдиного вікна", інформаційний веб-портал якого матиме WEB-інтерфейси державного контролю за дотриманням законодавства про харчові продукти та корми, ветеринарно-санітарного контролю, фрітосанітарного контролю, державних органів, що видають дозвільні документи.

В рамках функціонування "Смартмитниці” передбачено імплементацію нової комп'ютеризованої транзитної системи (New Computerised Transit System - NCTS), що є спільною європейською системою обміну електронними даними про товари, що переміщуються транзитом, між усіма митними органами-учасниками транзиту, а також митними органами та суб'єктами ЗЕД.

Ключовою особливістю інтеграції митної системи України відповідно до норм ЄС на основі зобов'язань України за економічною частиною Угоди про асоціацію з $€ С є$ приєднання до Конвенції про процедуру спільного транзиту, зокрема через програми EU4PFM, RST. Перевагою використання однієї транзитної декларації в межах Конвенції про процедуру спільного транзиту $є$ обмін митною інформацією з 35 країнами у режимі реального часу, зменшення затримок вантажів на кордоні через зростання ефективності здійснення аналізу ризиків та визначення переліку необхідних контрольних процедур щодо товарів ще до їх прибуття на митний кордон України, зменшення вартості митних процедур, формування безпечних ланцюгів постачання товарів, надання суттєвих спрощень митних формальностей для підприємств 3 високим ступенем довіри, підвищення ефективності ведення їх бізнесу за рахунок економії часових та фрінансових витрат.

Процес запровадження режиму NCTS, відповідно до зобов'язань, розпочався у листопаді 2020 р., з виокремленням трьох 
етапів реалізації: пілотного проекту, національного та міжнародного застосування. При цьому перша транзитна декларація в пілотному форматі була випущена у режим спільного транзиту 5 грудня 2020 р.

Однак, відповідно до статті 84 та Додатку XV Угоди про асоціацію, Україна мала впровадити положення Конвенції протягом одного року від дати набуття чинності Угоди про асоціацію, тобто станом на 1 вересня 2018 р. Недотримання встановлених часових меж імплементації положень Конвенції зумовлено низкою причин:

- по-перше, митне законодавство та підзаконні нормативні акти України значною мірою не відповідають положенням Конвенції про спільну транзитну процедуру. Для приведення їх у відповідність необхідними є:

а) внесення змін до Митного кодексу України та законодавства, що регулюватимуть питання претензійної роботи між митними органами різних держав, обміну інформації при розслідуваннях втрати вантажів, стягнення та повернення гарантій нерезидентам;

б) доповнення діючих нормативно-правових актів митного законодавства України в частині відповідності термінології, системи гарантій, що застосовуються до транзитного переміщення товарів та митних формальностей під час спільної транзитної процедури;

в) розробка нормативно-правового та інституційного підґрунтя запуску прикладного програмного забезпечення для національної підсистеми NCTS;

- по-друге, за умови внесення всіх необхідних змін до національного законодавства, ключовою умовою початку тестової експлуатації режиму NCTS в Україні є:

а) створення та запуск національної транзитної підсистеми з рекомен- дованими ЄC до використання в митному просторі країн-кандидатів програмними модулями (Minimal Common Core (MCC) та EDIFACT $\mathrm{CCN} / \mathrm{CSI}$ (ECN);

б) фрункціонування в Україні паралельно з NCTS інших систем контролю за транзитом (національний "внутрішній” транзит, транзит за іншими міжнародними угодами тощо), зумовлює необхідність детального аналізу умов та співіснування таких систем (наприклад, у рамках Дорожньої карти приєднання України до спільної транзитної процедури ЄС/ЄАВТ);

- по-третє, для початку тестової експлуатації системи NCTS, окрім законодавчого, важливим $€$ технологічний базис, що охоплює прикладні програми національної підсистеми NCTS та національний вузол для підключення до захищеної мережі, в якій відбувається обмін інформацією про спільні транзитні процедури. Практичною вимогою європейської сторони до України для приєднання до Конвенції $є$ результативна, річна тестова експлуатація національної підсистеми NCTS як інформаційно-телекомунікаційної системи, в якій здійснюється обробка транзитних декларацій, аналіз службової інформації, що стосується спільної транзитної процедури, відбувається обмін інформацією між митними органами різних країн. Однак ті елементи Конвенції, що вже запроваджені Україною (коди, класифікатори та подібне), є недостатніми для початку роботи NCTS в Україні.

Існування означених складностей зумовлює необхідність активізації законодавчих, технічних та інституційних заходів 3 метою прискорення запровадження новітніх інформаційних систем в практичну діяльність митних органів України. 
Висновки. Тенденції світового розвитку економічних процесів в умовах цифровізації встановлюють нові завдання зі спрощення митних процедур, для реалізації яких необхідно забезпечити функціонування сучасних, доступних, керованих і кібербезпечних електронних інформаційних систем, які працюють відповідно до ключових принципів ефрективності інфрормаційного забезпечення митної справи (табл. 4).

Митні органи України впродовж усього періоду незалежності проводять цілеспрямовану роботу із широкого впровадження інформаційно-телекомунікаційних технологій митного оформлення та контролю. Однак, в умовах цифрової стратегії розвитку суспільства, вдосконалення інформаційного забезпечення ДМС України відповідно до європейських і міжнародних вимог, на наше переконання, має здійснюватись одночасно в трьох напрямках:

1) технологічному, із забезпеченням належного рівня розвитку інформаційних систем, їх технічних, технологічних, безпекових, сертифокаційних і стандартизованих характеристик;

2) інституційному, що полягає у фрормуванні належного законодавчого, нормативно-правового та методологічного забезпечення, адекватного міжнародним вимогам до інформаційних систем у сорері обробки, аналізу та систематизації інформації у митній справі;

3) інфрраструктурному, що охоплює інфрормаційні продукти, які забезпечують належний обмін інформацією як між інформаційними базами митних органів України, суб'єктів ЗЕД, так і міжнародними учасниками.

\section{Основні принципи інформаційного забезпечення митної справи України}

Таблиця 4 в умовах цифрової стратегії розвитку*

\begin{tabular}{|c|c|}
\hline Принцип & Зміст і значення \\
\hline Доступність & $\begin{array}{l}\text { Наявність однакових умов доступу до послуг та інформації як для суб'єктів ЗЕД, так } \\
\text { і для державних органів на основі інфоормаційно-комунікаційних технологій }\end{array}$ \\
\hline Доцільність & $\begin{array}{l}\text { Використання цифрових технологій має сприяти створенню низки переваг для гро- } \\
\text { мадян, держави, фіскальних інституцій та суб'єктів ЗЕД }\end{array}$ \\
\hline $\begin{array}{l}\text { Економічна на- } \\
\text { ціленість }\end{array}$ & $\begin{array}{l}\text { Суть принципу полягає в досягненні ефективності діяльності для учасників за умови } \\
\text { використання цифрових технологій відповідно до регіональних, національних про- } \\
\text { грам та стратегій цифровізації економіки, її сфрер і галузей у нових характеристиках } \\
\text { ефективності }\end{array}$ \\
\hline Транспарентність & $\begin{array}{l}\text { Здатність одержувати, передавати та використовувати інформацію для створення, } \\
\text { накопичення, поширення, переробки та перевірки інформації, її достовірності та } \\
\text { правильності. Здатність національних інформаційних систем інтегруватися в регіо- } \\
\text { нальні, європейські та міжнародні системи обміну інформацією }\end{array}$ \\
\hline Стандар & $\begin{array}{l}\text { Відповідність відкритим, ффункціонально сумісним європейським та міжнародним } \\
\text { стандартам поширення інформаційних систем та технологій }\end{array}$ \\
\hline Безпековість & $\begin{array}{l}\text { Означений принцип декларує необхідність захисту конфіденційності персональної } \\
\text { інформації, забезпечення інформаційної безпеки та кібербезпеки інформаційних } \\
\text { систем, які використовують суб'єкти митної справи }\end{array}$ \\
\hline Комплексність & $\begin{array}{l}\text { Інформаційні технології, які використовують митні органи, мають бути частиною } \\
\text { “цифрової” програми розвитку держави, а також компліментарними і взаємоузг- } \\
\text { дженими з іншими національними і регіональними інфоормаційними системами }\end{array}$ \\
\hline
\end{tabular}

\footnotetext{
* Складено авторами.
} 
У подальших наукових дослідженнях необхідно зосередити увагу на оцінці рівня ефективності використання інформаційних технологій та інформаційного забезпечення митних органів України і розвинених держав світу, з аналізом безпекових, фріскальних та економічних ефектів їх використання при здійсненні митного оформлення та митного контролю.

\section{Список використаних джерел}

1. Dunleavy P., Margetts H., Bastow S., Tinkler J. Digital Era Governance: IT Corporations, the State and E-Government. Oxford: Oxford University Press, 2006. 302 p.

2. Войцещук А.Д. Як працює нова автоматизована система управління ризиками на митниці? Дебет-кредит. URL : https://news.dtkt. ua/state/zed/53042.

3. Давидов Р. Щодо автоматизації митних процедур: прес центр. URL : http://www. wcoomd.org//media/wco/public/global/pdf/medial annualreports/wco_ar_2016_2017_en.pdf.

4. Івашова Л. М., Кийда Л. І., Спрощений митний контроль у контексті економічної безпеки: проблеми та шляхи їх розв'язання. Вiсник Академії митної служби України. Державне управління. 2012. № 1(6). С. 146-152.

5. Пашко П. В., Шуляк В. П. “Електронна митниця" - головний механізм гарантування митної безпеки держави / Фінанси України. 2006. № 12. С. 53-59.

6. Разумей М. М. Особливості застосування автоматизованої системи аналізу та управління ризиками, основною метою якої $є$ забезпечення вибірковості митного контролю. URL : http://chp.com.ua/all-news/item/60270-osoblivostizastosuvannya-avtomatizovanoji-sistemi-analizuta-upravlinnyarizikami-osnovnoyu-metoyu-yakojiezabezpechennya-vibirkovosti-mitnogo-kontrolyu.

7. Керівні принципи для митної справи України. URL : http://www.chamber.ua/Content/ Documents/1140630383Guidelines for Customs Policy in_Ukraine_UA.pdf.
8. EUR-Lex. Access to European Union Law. Communication from the Commission to the Council, the European Parliament, the European Economic and Social committee and the Committee of the Regions on Short Sea Shipping URL : http://eur-lex.europa.eu/legal-content/EN/ ALL/?uri=CELEX\%3A52004DC0453.

9. World Customs organization. Official site. URL : http://www.wcoomd.org.

10. Ооріційний сайт Державної митної служби. URL : https://customs.gov.ua.

11. Про затвердження Порядку застосування автоматизованої системи аналізу та управління ризиками під час митного контролю та митного офрормлення товарів із застосуванням вантажної митної декларації. Наказ ДМСУ від 13.12.2010 p. № 1467. URL : http:// zakon4.rada.gov.ua/laws/show/z0180-11.

12. Про затвердження Концепції створення, упровадження і розвитку системи електронного декларування товарів. Наказ ДМСУ від 18.10.2006 p. № 907. URL : https://zakon.rada.gov. ua/rada/show/v0907342-06.

13. Про Концепцію інтегрування системоутворюючих компонентів технічних та спеціальних засобів митного контролю з автоматизованою системою митного оформлення Держмитслужби України. Наказ ДМСУ від 28.03.12 p. № 191. URL : https://zakon.rada.gov. ua/rada/show/v0191342-12.

14. Про затвердження Положення про інформаційно-телекомунікаційну систему відеоконтролю Державної фріскальної служби України. Наказ від 10.02.2016 № 43. URL : https:// zakon.rada.gov.ua/laws/show/z0302-16\#Text.

15. Про затвердження Положення про Єдину автоматизовану інфрормаційну систему Держмитслужби України. Наказ від 04.11.2010 № 1341. URL : https://zakon.rada.gov.ua/rada/ show/va341342-10\#Text.

16. Про затвердження Порядку взаємодії інфоормаційних систем Державної податкової служби України та Державної митної служби України щодо обміну інформацією, необхідною 
для адміністрування податків, зборів та інших обов'язкових платежів, здійснення контрольних процедур щодо дотримання податкового та митного законодавства. Наказ Міністерства фрінансів України від 10.06.2020 № 286. URL : https:// zakon.rada.gov.ua/laws/show/z0593-20\#Text.

17. Цифрова адженда України - 2020 (“Цифровий порядок денний” - 2020). Концептуальні засади (версія 1.0). Першочергові сфрери, ініціативи, проекти “цифровізації” України до 2020 року. URL : https://ucci.org.ua/uploads/ files/58e78ee3c3922.pdf.

18. Electronic customs. European Commission. Taxation and customs union. URL : https:// ec.europa.eu/taxation customs/general-information-customs/electronic-customs en.

\section{References}

1. Dunleavy, P., Margetts, H., Bastow, S., Tinkler, J. (2006). Digital Era Governance: IT Corporations, the State and E-Government. Oxford: Oxford University Press.

2. Voytseshchuk, A.D. (2019). Yak pratsiuie nova avtomatyzovana systema upravlinnia ryzykamy na mytnytsi? [How does the new automated risk management system at customs work?]. Debetkredyt - Debit credit. Available at: https://news.dtkt. ua/state/zed/53042.

3. Davydov, R. Shchodo avtomatyzatsii mytnykh protsedur: pres tsentr [On automation of customs procedures: press center]. Available at: http:// www.wcoomd.org/-/media/wco/public/global/pdf/ media/annual-reports/wco ar 2016-2017 en.pdf.

4. Ivashova, L.M., Kyida, L.I. (2012). Sproshchenyi mytnyi kontrol $u$ konteksti ekonomichnoi bezpeky: problemy ta shliakhy yikh rozviazannia [Simplified customs control in the context of economic security: problems and ways to solve them]. Visnyk Akademii mytnoi sluzhby Ukrainy. Derzhavne upravlinnia - Bulletin of the Academy of Customs Service of Ukraine. Public Administration Series, 1 (6), 146-152 [in Ukrainian].

5. Pashko, P.V., Shuliak, V.P. (2006). "Elektronna mytnytsia" - holovnyi mekhanizm harantuvannia mytnoi bezpeky derzhavy ["Electronic customs" the main mechanism for guaranteeing customs security of the state]. Finansy Ukrainy - Finance of Ukraine, 12, 53-59 [in Ukrainian].

6. Razumey, M. M. (2019). Osoblyvosti zastosuvannia avtomatyzovanoi systemy analizu ta upravlinnia ryzykamy, osnovnoiu metoiu yakoi ye zabezpechennia vybirkovosti mytnoho kontroliu [Features of application of an automated system of risk analysis and management, the main purpose of which is to ensure the selectivity of customs control]. Available at: http://chp.com.ua/all-news/ item/60270-personal-appropriate-automatizedsystem-analysis-to230upravlinny-pricing-main-ymetoyu-yakoji-e-zabezpechenny-vibirkovosti-mitnogo-kontrollyu.

7. Kerivni pryntsypy dlia mitnoi spravy Ukrainy [Guidelines for the customs business of Ukraine]. Available at: http://www.chamber.ua/Content/ Documents/1140630383Guidelines for Customs Policy in Ukraine UA.pdf.

8. EUR-Lex. Access to European Union Law. Communication from the Commission to the Council, the European Parliament, the European Economic and Social committee and the Committee of the Regions on Short Sea Shipping. Available at: http://eur-lex.europa.eu/legal-content/ EN/ALL/?uri=CELEX\%3A52004DC0453.

9. World Customs organization. Official site. Available at: http://www.wcoomd.org.

10. Ofitsiinyi sait Derzhavnoi mitnoi sluzhby [Official site of the State Customs Service]. Available at: https://customs.gov.ua.

11. Pro zatverdzhennia Poriadku zastosuvannia avtomatyzovanoi systemy analizu ta upravlinnia ryzykamy pid chas mytnoho kontroliu ta mytnoho oformlennia tovariv iz zastosuvanniam vantazhnoi mytnoi deklaratsii. Nakaz DMSU vid 13.12.2010 r. № 1467 [On approval of the Procedure for application of the automated system of analysis and risk management during customs control and customs clearance of goods with the use of cargo customs declaration. Order of the SCSU]. (2010, December, 13). Available at: http://zakon4.rada.gov.ua/laws/show/z0180-11. 


\section{МИТНА СПРАВА}

12. Pro zatverdzhennia Kontseptsii stvorennia, uprovadzhennia $i$ rozvytku systemy elektronnoho deklaruvannia tovariv. Nakaz DMSU vid 18.10.2006 r. № 907. [About the statement of the Concept of creation, introduction and development of system of electronic declaration of the goods. Order of the SCSU]. (2006, October, 18). Available at: https:// zakon.rada.gov.ua/rada/show/v0907342-06.

13. Pro Kontseptsiiu intehruvannia systemoutvoriuiuchykh komponentiv tekhnichnykh ta spetsialnykh zasobiv mytnoho kontroliu z avtomatyzovanoiu systemoiu mytnoho oformlennia Derzhmytsluzhby Ukrainy. Nakaz DMSU vid 28.03.12 r. № 191 [About the Concept of integration of system-forming components of technical and special means of customs control with the automated system of customs registration of the State Customs Service of Ukraine. Order of the SCSU]. (2012, March, 28). Available at: https://zakon.rada.gov.ua/ rada/show/v0191342-12.

14. Pro zatverdzhennia Polozhennia pro informatsiino-telekomunikatsiinu systemu videokontroliu Derzhavnoi fiskalnoi sluzhby Ukrainy. Polozhennia vid 10.02.2016 № 43 [On approval of the Regulation on the information and telecommunication systems of video surveillance of the State Fiscal Service of Ukraine. Order]. (2016, February, 10). Available at: https://zakon.rada.gov.ua/laws/ show/z0302-16\#Text.

15. Pro zatverdzhennia Polozhennia pro Yedynu avtomatyzovanu informatsiinu systemu Derzhmytsluzhby Ukrainy. Nakaz vid 04.11.2010 № 1341 [On approval of the Regulations on the Unified automated information system of the State Customs Service of Ukraine. Order]. (2010, November, 04). Available at: http://minrd.gov.ua/ baneryi/mitne-oformlennya/subektam-zed/elektronna-mitnitsya/62603.htm.
16. Pro zatverdzhennia Poriadku vzaiemodii informatsiinykh system Derzhavnoi podatkovoi sluzhby Ukrainy ta Derzhavnoi mytnoi sluzhby Ukrainy shchodo obminu informatsiieiu, neobkhidnoiu dlia administruvannia podatkiv, zboriv ta inshykh oboviazkovykh platezhiv, zdiisnennia kontrolnykh protsedur shchodo dotrymannia podatkovoho ta mytnoho zakonodavstva. Nakaz Ministerstva finansiv Ukrainy vid 10.06.2020 № 286 [On approval of the Procedure for interaction of information systems of the State Tax Service of Ukraine and the State Customs Service of Ukraine on the exchange of information necessary for the administration of taxes, fees and other mandatory payments, control procedures for tax and customs legislation. Order of the Ministry of Finance of Ukraine]. (2020, June, 10). Available at: https://zakon.rada.gov.ua/laws/show/ z0593-20\#Text.

17. Tsyfrova adzhenda Ukrainy - 2020 ("Tsyfrovyi poriadok dennyi" - 2020). Kontseptualni zasady (versiia 1.0). Pershocherhovi sfery, initsiatyvy, proekty "tsyfrovizatsii" Ukrainy do 2020 roku [Digital agenda of Ukraine - 2020. Conceptual basis (version 1.0). Priority areas, initiatives, projects of "digitalization" of Ukraine by 2020]. Available at: https:// ucci.org.ua/uploads/files/58e78ee3c3922.pdf.

18. Electronic customs. European Commission. Taxation and customs union. Available at: https://ec.europa.eu/taxation customs/general-information-customs/electronic-customs en.

Стаття надійшла до редакції 19.11.2020. 